\title{
A Study on Ceramsite Production Using Dredging Sea Mud and Its Biofilm Formation Capacity Evaluation
}

\author{
Ting Xia ${ }^{(D)}{ }^{1}$ Yue Li, ${ }^{1}$ Zhixing Xiao, ${ }^{1}$ Shixiang Wang, ${ }^{1}$ Qingkai Wu, ${ }^{1}$ Suwen Sun, ${ }^{1}$ Hui Peng, \\ Dan Chen, ${ }^{1}$ and Zhihua Wang $\mathbb{D}^{2}$ \\ ${ }^{1}$ College of Urban Construction, Nanjing Tech University, Nanjing 211816, China \\ ${ }^{2}$ Research Center of Urban Underground Space, Nanjing Tech University, Nanjing 210009, China
}

Correspondence should be addressed to Ting Xia; xiating@njtech.edu.cn and Zhihua Wang; wzhnjut@163.com

Received 4 June 2018; Revised 4 September 2018; Accepted 10 September 2018; Published 6 December 2018

Academic Editor: Dingwen Zhang

Copyright ( 92018 Ting Xia et al. This is an open access article distributed under the Creative Commons Attribution License, which permits unrestricted use, distribution, and reproduction in any medium, provided the original work is properly cited.

\begin{abstract}
Dredging sea mud produced during the coastal infrastructure construction has been gradually becoming an environmental problem in China. Making ceramsite is an attractive way to convert the waste sea mud to resources used for many industrial sectors. However, the imapct of preheating and sintering conditions on the ceramsite properties and the biofilm formation capacity of the ceramsite are still poorly understood. This study aims to fill these knowledge gaps. Results suggested the optimal conditions for the preheating temperature was $350^{\circ} \mathrm{C}$, the preheating time was $15 \mathrm{~min}$, the sintering temperature was $1040^{\circ} \mathrm{C}$, and the sintering time was $9 \mathrm{~min}$. The dredging sea mud-derived ceramsite showed better biofilm formation capacity with high COD and $\mathrm{NH}_{4}{ }^{+}-\mathrm{N}$ removal performance compared with the commercial ceramsites. The content of the chloride ion in the ceramist granules is close to zero, and the low cost of this material, implying this dredging sea mud-derived ceramsite, could be an engineering favorable material for using it as a biocarrier in the real application.
\end{abstract}

\section{Introduction}

The development of the marine economy has led to a dramatic increase in infrastructure construction activities and transportation industry in coastal areas [1]. Accordingly, a large amount of dredging sea mud (DSM) has been produced. The improper disposal of these mud not only takes up a lot of space but also causes environmental pollution and other problems (odour, disease, etc.,). Thus, safety treatment of these DSM has received considerable attention $[2,3]$.

The commonly used DSM treatment methods mainly are physicochemical methods, such as solidification; Zhu et al. [4] conducted dredging mud solidification treatment, confirming that the solidificated dredging mud could be utilized as solid filler material. In addition, DSM contains some organic matter and, therefore, could be utilized in agriculture and aquaculture. Xie et al. [5] confirmed that DSM can be used in agricultural cultivation. Besides these methods described above, an important way to treat waste DSM is to be the raw materials for sintering the ceramsite. Chi et al. [6] used seabed sludge for ceramsite production, and the results showed that the product performance fully meets the requirements of the Chinese national technical standards for clay ceramsite. Ceramsite is a commonly used biocarrier for biofilm formation in sewage and biological contact oxidation wastewater treatment process. The rough surface and internal porous structure provide good adsorption capacity for pollutants removal, and also it is easy to grow microorganisms on its surface for biofilm formation.

Traditionally, nonrenewable natural resources, such as clay and shale, have been employed for the preparation of ceramsite by the method of high-temperature sintering $[7,8]$. In recent years, the use of wastes, such as sewage sludge, coal fly ash, mine tailings, and river sediment, as the raw material for ceramsite sintering has been received increasing attention [8-11]. There is a relatively less study investigating the DSM for the production of ceramsite. DSM could be one of the best substitutes for clay because its major components are similar to those of clay. In our previous study, we have prepared ceramsite by using the mixture of DSM, sewage sludge, and the additive of calcium carbonate $[12,13]$. The produced ceramsite met the Chinese standard 
GB/T 17431.1-2010. Although Chi et al. [6] produced ceramsite successfully by the single raw material of sedimented sea mud in Qingdao, China, the sintering mechanism was not revealed deeply. In addition, DSM has more salinity and water than clay. In the sintering process of DSM, many researchers worry that chloride has undesirable effects including scumming $[14,15]$. The content of the soluble salt in the sea mud is likely to relate to the preheating and sintering temperature $[6,15]$.

Thus, the aim of this study is to investigate the impact of preheating and sintering conditions on the properties of DSM-derived ceramsite. In addition, for further application as biocarrier, the capacity of water purification and the biofilm formation of DSM-derived ceramsite was also evaluated.

\section{Materials and Methods}

2.1. Characteristics of DSM. The DSM was collected from a coastal site which located in Lianyungang, Jiangsu province, China (N34 $\left.46^{\prime} 15.32^{\prime \prime}, \mathrm{E} 119^{\circ} 19^{\prime} 24.74^{\prime \prime}\right)$. The color of this DSM is dark with salty smell. The DSM was sieved firstly to remove the large-sized agglomerates, followed by its property analysis according to the "Standard for Soil Test Method" (HJ 835-2017). The results are shown in Table 1:

\subsection{The Feasibility of DSM from Lianyungang for Ceramsite} Sintering. The DSM collected from different coastal areas may have different properties. To meet the ceramsite-forming conditions, the raw chemical composition range for the sintering ceramsite is generally on the basis of Riley and Wilson's research. Table 2 shows the main chemical composition of the raw material from Lianyungang by the EDX, and the content of major chemical composition of DSM complies with Riley's three-phase diagram and the required chemical composition range for making ceramsite. It can be seen from the table that the DSM from Lianyungang is expected to be sintered into ceramsite alone. Because LOI in the raw material is up to $8.58 \%$, the ceramsite would be with high porosity. The feasibility of DSM from Lianyungang for ceramsite sintering was further studied by comparing the basic properties of DSM with clay materials which are conventional raw material for ceramsite sintering, and Table 3 shows the different properties. It can be seen that the DSM has a higher water content than clay, reaching $50 \%-60 \%$. The composition of DSM is mainly composed of clay and powder, and the plasticity index is excellent, so it is judged that the DSM is easy for granulation. At the same time, the salt content of the DSM (mostly sodium chloride) is high, and the transformation process of chlorine should be concerned in the sintering process. The DSM from Lianyungang is used as a single raw material to form a ceramsite by molding, drying, preheating, and sintering. The ceramsite with a particle size of $3 \sim 5 \mathrm{~mm}$ is selected for use in the following experiment.

2.3. DSM Ceramsite Presintering Experiment. In order to determine the main process conditions that need to be controlled during the ceramsite sintering process, it is necessary to set up a presintering experiment before the optimization process to determine the effect of the preheating conditions and the sintering conditions on ceramsite properties.

Because the moisture content of the DSM is high and the evaporation of the combined water in the raw material is about $250^{\circ} \mathrm{C}$. Wang et al. [16] used TGA-FTIR technology to study the combustion and pyrolysis characteristics of sludge from different sources and pointed out that the decomposition temperature of organic matter is about $350^{\circ} \mathrm{C}$. Therefore, the preheating temperature in this study can be set in the range of $250 \sim 400^{\circ} \mathrm{C}$, and the preheating time can be set in the range of 5 20 min [17]. The sintering temperature in this study is mainly determined by reference to the sintering temperature of the high-temperature sintered clay ceramsite, and the sintering time ranges from 6 to 15 minutes [18]. The presintering experimental design is shown in Table 4, and the results of the presintering experiment are shown in Table 5.

According to the results of the presintering experiment, the preheating temperature can be set in the range of $200 \sim 450^{\circ} \mathrm{C}$, and the preheating time is preferably in the range of $10 \sim 20 \mathrm{~min}$. When the sintering temperature is varied from $1000 \sim 1100^{\circ} \mathrm{C}$, it is possible to obtain ceramsite with good performance. According to the results of the presintering experiment, the sintering time can be set at $6 \sim 12 \mathrm{~min}$.

2.4. Effect of Preheating Conditions on Ceramsite Properties. According to the results of the presintering experiment, three preheating time periods ( $10 \mathrm{~min}, 15 \mathrm{~min}$, and $20 \mathrm{~min}$ ) were selected to investigate the effect of the preheating method on ceramsite properties. The preheating temperature was controlled between $200 \sim 450^{\circ} \mathrm{C}$, and the temperature increase rate was $8^{\circ} \mathrm{C} / \mathrm{min}$ [19]. The properties of ceramsite, such as expansion rate, bulk density, compressive strength, and water absorption, were compared.

\subsection{Effect of Sintering Conditions on Ceramsite Properties.} According to the results of the presintering experiment, three sintering time periods ( $6 \mathrm{~min}, 9 \mathrm{~min}$, and $12 \mathrm{~min}$ ) were selected to investigate the effect of the sintering method on ceramsite properties. The sintering temperature was controlled between $1000 \sim 1080^{\circ} \mathrm{C}$, and the temperature increase rate was $10^{\circ} \mathrm{C} / \mathrm{min}$; the properties of ceramsite, such as expansion rate, bulk density, compressive strength, and water absorption, were compared.

2.6. Analysis of Dissolved Salts Transformation during Ceramsite Production. The $\mathrm{Cl}^{-}$content variation during ceramsite sintering was studied by measuring the $\mathrm{Cl}^{-}$ content under different sintering temperatures. The DSM under different temperatures were sampled and grinded, and the powder was then dissolved into the ultrapure water with mild vibration; after 1 day, the DSM powder suspension was filtered. The filtrate was then subjected to $\mathrm{Cl}^{-}$analysis.

2.7. Sea Mud-Derived Ceramsite as Biofilm Carrier for COD and $\mathrm{NH}_{4}{ }^{+}-\mathrm{N}$ Removal. A plexiglass column $(\Phi 10 \mathrm{~cm} \times$ 
TABle 1: The properties of dredged sea mud.

\begin{tabular}{lccccr}
\hline $\begin{array}{l}\text { Density } \\
\left(\mathrm{g} \mathrm{cm}^{-3}\right)\end{array}$ & $\begin{array}{c}\text { Water content } \\
(\%)\end{array}$ & $\begin{array}{c}\text { Liquid limit } \\
(\%)\end{array}$ & $\begin{array}{c}\text { Plastic limit } \\
(\%)\end{array}$ & Particle-size distribution (\%) & Property \\
\hline 1.45 & $50-60$ & $23-28$ & $45-58$ & Clay (50.5) powder (49.5) & Saturated low liquid limit clayey silt \\
\hline
\end{tabular}

TABle 2: Chemical composition (\%) of DSM.

\begin{tabular}{lccccccc}
\hline Item & $\mathrm{SiO}_{2}$ & $\mathrm{Al}_{2} \mathrm{O}_{3}$ & $\mathrm{Fe}_{2} \mathrm{O}_{3}$ & $\mathrm{CaO}$ & $\mathrm{MgO}$ & $\mathrm{K}_{2} \mathrm{O}$ & $\mathrm{Na}_{2} \mathrm{O}$ \\
\hline $\begin{array}{l}\text { Sea mud } \\
\begin{array}{l}\text { Riley's three-phase } \\
\text { diagram }\end{array}\end{array}$ & 57.10 & 17.30 & 11.30 & 3.10 & 2.17 & 4.01 & 3.01 \\
\hline
\end{tabular}

TABLE 3: The properties of DSM and clay materials.

\begin{tabular}{|c|c|c|}
\hline Item & DSM & Clay \\
\hline Water content (\%) & $50-60$ & $15-30$ \\
\hline $\begin{array}{l}\text { Particle } \\
\text { characteristics }\end{array}$ & $\begin{array}{l}\text { Mainly based on clay } \\
\text { and powder and } \\
\text { contains a small } \\
\text { amount of fine sand }\end{array}$ & $\begin{array}{l}\text { Thicker particles } \\
\text { and contains sand- } \\
\text { sized particles }\end{array}$ \\
\hline Liquid/plastic limit & High & Middle \\
\hline Salt content & High & Low \\
\hline $\begin{array}{l}\text { Chemical } \\
\text { composition }\end{array}$ & $\begin{array}{l}\text { Mainly silicon and } \\
\text { aluminum } \\
\text { High fused } \\
\text { ingredients content }\end{array}$ & $\begin{array}{l}\text { Mainly silicon and } \\
\text { aluminum } \\
\text { Low fused } \\
\text { ingredients content }\end{array}$ \\
\hline
\end{tabular}

TABle 4: Presintering experimental design.

\begin{tabular}{lcccc}
\hline Factor/level & 1 & 2 & 3 & 4 \\
\hline $\mathrm{A}(\mathrm{min})$ & 5 & 10 & 15 & 20 \\
$\mathrm{~B}\left({ }^{\circ} \mathrm{C}\right)$ & 250 & 300 & 350 & 400 \\
$\mathrm{C}(\mathrm{min})$ & 6 & 9 & 12 & 15 \\
$\mathrm{D}\left({ }^{\circ} \mathrm{C}\right)$ & 900 & 1000 & 1100 & 1200 \\
\hline
\end{tabular}

$60 \mathrm{~cm}$ ) packed with sea mud-derived ceramsite or commercial ceramsite with a particle size of $3-5 \mathrm{~cm}$ is used for hanging the biofilm and removing the $\mathrm{COD}$ and $\mathrm{NH}_{4}{ }^{+}-\mathrm{N}$. An air pump for column aeration was connected, and the flow rate was $20 \mathrm{~L} \cdot \mathrm{min}^{-1}$. After ceramsite installation was completed, a synthetic wastewater (COD: $12 \mathrm{mg} / \mathrm{L} ; \mathrm{NH}_{4}{ }^{+}-\mathrm{N}$ : $5 \mathrm{mg} / \mathrm{L}$ ) was filled into the column, and the wastewater was intercirculated and aerated during experiment; the water samples were taken periodically for measurement.

2.8. Analysis Methods. EDX analysis: the chemical composition of the raw material was measured by using an inductively coupled plasma emission spectrometer. XRD analysis: the mineral composition of sea mud raw material and sea mud-derived ceramsite was analyzed by using an X-ray diffraction analyzer. SEM analysis: the internal structure of sea mud raw material and sea mud derivedceramsite was analyzed by using a scanning electron microscope. The $\mathrm{Cl}^{-}$ion solubility of sea mud samples sintering at different temperatures was analyzed by the Wantong ion chromatograph. COD was determined using potassium permanganate titration. $\mathrm{NH}_{4}{ }^{+}-\mathrm{N}$ was determined using Nessler's reagent method.

\section{Results and Discussion}

3.1. Ceramsite Sintering by DSM from Lianyungang. According to Tables 1 and 2, the plasticity index of DSM is excellent. The content of major chemical composition of dredged sea mud complies with the Riley's three-phase diagram.

Figure 1 showed the XRD patterns of the mineral composition of DSM and DSM-derived ceramsite. Compared with the raw materials, kalisilite $\left(\mathrm{KAlSiO}_{4}\right)$ was not detected in ceramsite. This may due to the minerals contained in the raw materials (mainly oxides of Fe oxides and alkaline metal oxides) transformed and produced to fenaksite $\left[\mathrm{KNaFe}\left(\mathrm{Si}_{4} \mathrm{O}_{10}\right)\right]$ under high temperature. In addition, anorthoclase $\left(\mathrm{KAlSi}_{3} \mathrm{O}_{8}\right)$ and brinrobertsite $[(\mathrm{Na}, \mathrm{K}$, $\left.\mathrm{Ca})_{x}(\mathrm{Al}, \mathrm{Fe}, \mathrm{Mg})_{4}(\mathrm{Si}, \mathrm{Al})_{8} \mathrm{O}_{20}(\mathrm{OH})_{4} * 3.54\left(\mathrm{H}_{2} \mathrm{O}\right)(x=0.35)\right]$ recombination at high temperature may generate albitecalcium $\left[\mathrm{NaCaAl}(\mathrm{SiAl})_{2} \mathrm{O}_{8}\right]$.

The SEM images of surfaces of DSM and the DSMderived ceramsite are shown in Figure 2. Compared with ceramsite (Figure 2(b)), the structure of the raw materials of DSM (Figure 2(a)) is more loosely arranged. The particle size of DSM is different, and the shape is irregular. The quantity of pores in ceramsite (Figure 2(b)) is more than that in the raw materials (Figure 2(a)). The more micropores and the irregular surface may contribute higher porosity and specific surface area of sea mud-derived ceramsite.

\subsection{Effect of Preheating Conditions on Ceramsite Properties.} The preheating temperature and preheating time greatly impact the properties of the ceramsite, such as the formation of pottery and the pore and strength characteristics of the ceramsite. Here, the preheating time was controlled as $10 \mathrm{~min}, 15 \mathrm{~min}$, and $20 \mathrm{~min}$, respectively. The preheating temperature and heating rate were described in Section 2.3. The bulk density, water absorption, compressive strength, and expansion rate were analyzed under different preheating time periods.

Figure 3(a) shows that, at the same preheating temperature, with the prolonging of the preheating time of the raw material, the bulk density of the ceramsite decreased. In 
TABLE 5: Presintering results.

\begin{tabular}{|c|c|c|c|c|c|c|c|c|}
\hline No. & $\mathrm{A}\left(X_{1}\right)(\min )$ & $\mathrm{B}\left(X_{2}\right)\left({ }^{\circ} \mathrm{C}\right)$ & $\mathrm{C}\left(X_{3}\right)(\min )$ & $\mathrm{D}\left(X_{4}\right)\left({ }^{\circ} \mathrm{C}\right)$ & $\begin{array}{c}\text { Bulk } \\
\text { density }\left(\mathrm{g} \cdot \mathrm{cm}^{-3}\right)\end{array}$ & $\begin{array}{c}\text { Water } \\
\text { absorption (\%) }\end{array}$ & $\begin{array}{c}\text { Compressive } \\
\text { strength }(\mathrm{MPa})\end{array}$ & $\begin{array}{c}\text { Expansion } \\
\text { rate }(\%)\end{array}$ \\
\hline 1 & 5 & 250 & 6 & 900 & 797 & 46 & 0 & 1.01 \\
\hline 2 & 5 & 300 & 9 & 1000 & 674 & 18.7 & 2.29 & 1.3 \\
\hline 3 & 5 & 350 & 12 & 1100 & 617 & 16 & 3.7 & 1.3 \\
\hline 4 & 5 & 400 & 15 & 1200 & 1 & 1 & / & I \\
\hline 5 & 10 & 250 & 9 & 1100 & 553 & 19 & 3.3 & 1.3 \\
\hline 6 & 10 & 300 & 6 & 1200 & I & 1 & I & I \\
\hline 7 & 10 & 350 & 15 & 900 & 756 & 28 & O & 1.3 \\
\hline 8 & 10 & 400 & 12 & 1000 & 623 & 12.7 & 4.1 & 1.7 \\
\hline 9 & 15 & 250 & 12 & 1200 & I & 1 & I & I \\
\hline 10 & 15 & 300 & 15 & 1100 & 455 & 35.3 & 3.5 & 1.2 \\
\hline 11 & 15 & 350 & 6 & 1000 & 695 & 22 & 2.7 & 2.0 \\
\hline 12 & 15 & 400 & 9 & 900 & 763 & 36 & 0 & 1.5 \\
\hline 13 & 20 & 250 & 15 & 1000 & 665 & 25 & 2.8 & 1.7 \\
\hline 14 & 20 & 300 & 12 & 900 & 749 & 20 & 0 & 1.5 \\
\hline 15 & 20 & 350 & 9 & 1200 & 1 & 1 & I & 1 \\
\hline 16 & 20 & 400 & 6 & 1100 & 578 & 14 & 3.8 & 1.4 \\
\hline
\end{tabular}

Note: "O" means that it is not made into ceramsite and "l" means that the ceramsite is overfired.

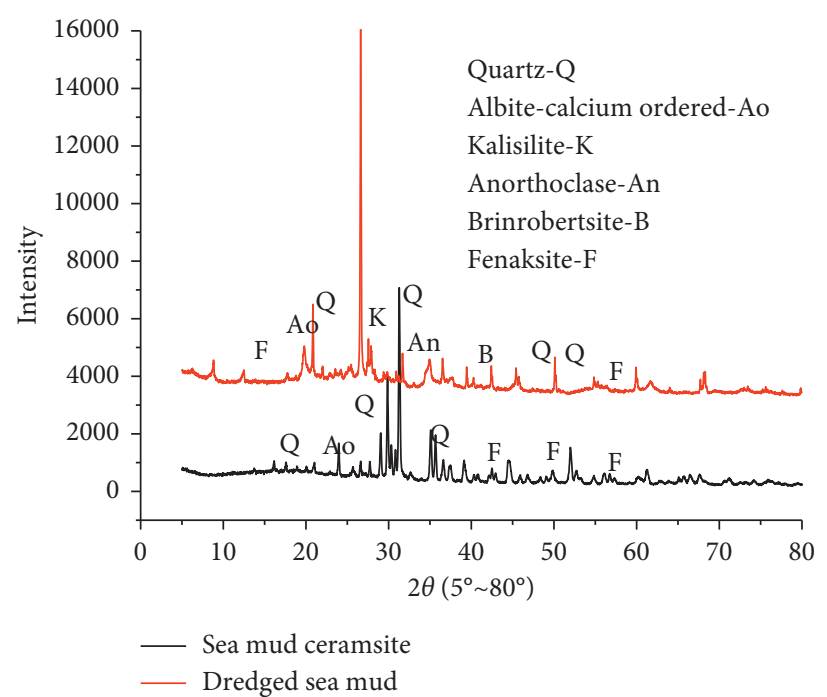

FIGURE 1: XRD analysis results on DSM and ceramsite. Q: quartz; Ao: albite-calcium ordered; K: kalisilite; An: anorthoclase; B: brinrobertsite; F: fenaksite.
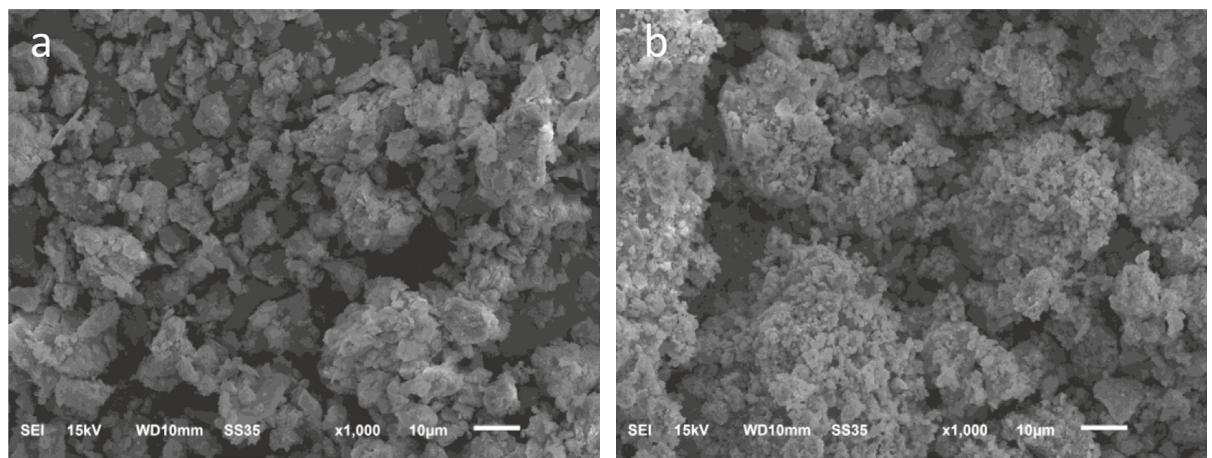

FIgURE 2: Scanning electron microscope image of (a) raw material 1000× and (b) ceramsites 1000x. 


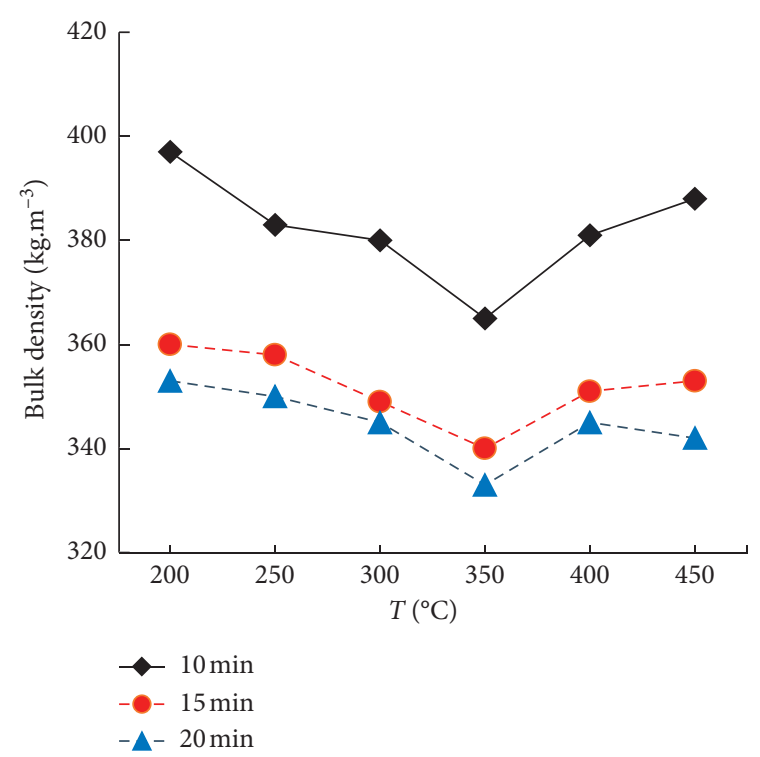

(a)

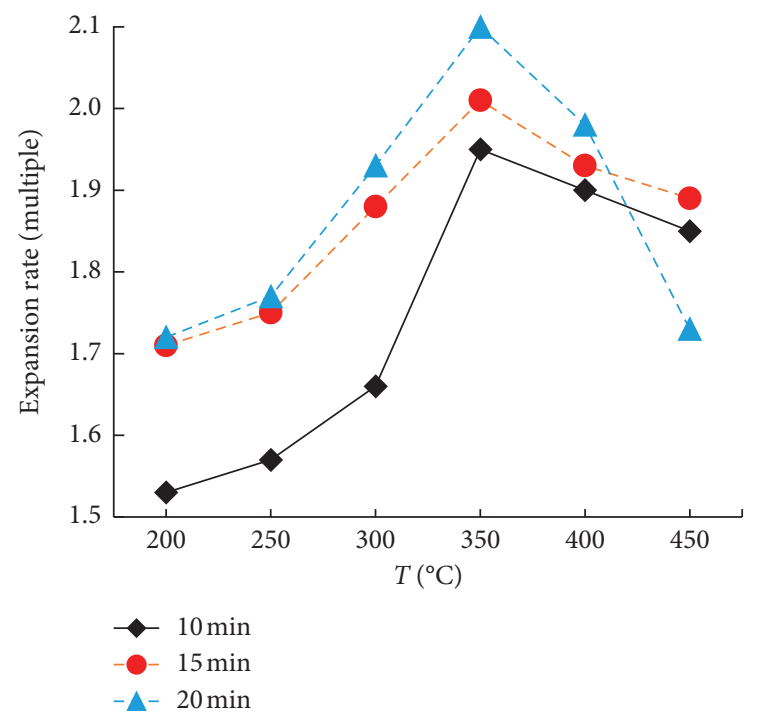

(c)

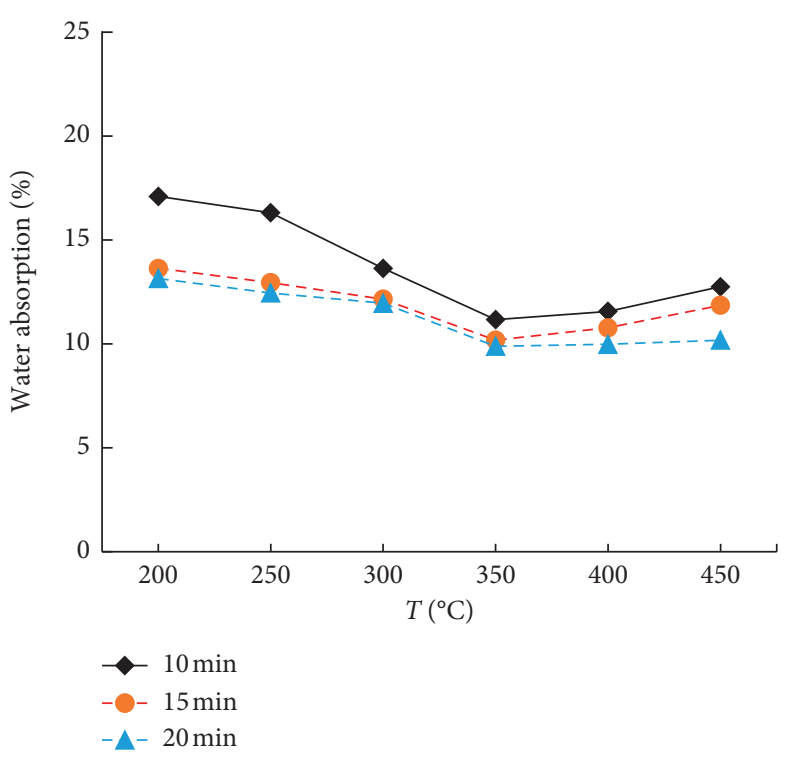

(b)

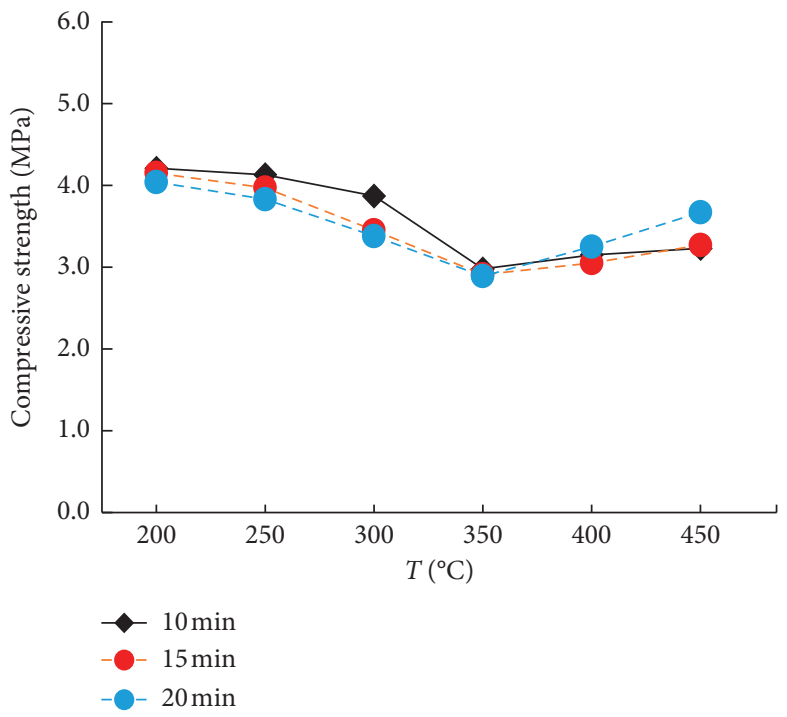

(d)

FIGURE 3: Effect of the preheating system on the performance of ceramsite. (a) Bulk density-temperature curve; (b) water absorptiontemperature curve; (c) expansion rate-temperature curve; (d) compressive strength-temperature curve.

addition, $350^{\circ} \mathrm{C}$ seems to be an inflection point because the bulk density showed the decreasing trend when the preheating temperature was increased from $200 \sim 350^{\circ} \mathrm{C}$ and increasing as the temperature continued to rise.

Figure 3(b) showed that the water absorption rate of the ceramsite slightly decreased with the prolongation of the preheating time, although the water absorption rate of ceramsite under $15 \mathrm{~min}$ preheating was similar with that under $20 \mathrm{~min}$. In the similar manner, the water absorption rate was decreased firstly and increased after the preheating temperature was above $350^{\circ} \mathrm{C}$.

Figure 3(c) shows that the degree of swelling of the ceramsite is greatly influenced by the preheating temperature. The longer the preheating time, the more the swelling of ceramsite when preheating temperature was below $400^{\circ} \mathrm{C}$.
It is very interesting that the variation of the expansion rate of ceramsite showed an inverse trend compared with other property index, which increased firstly and decreased when the preheating temperature was above $350^{\circ} \mathrm{C}$. Different from other index, the compressive strength of ceramsite is less affected by the preheating time and temperature.

The above test results suggested that changes in the preheating temperature and preheating time of the raw material have a great influence on the bulk density and the expansion rate of the ceramsite and a slight influence on the water absorption rate.

According to the analysis, this phenomenon is mainly related to the preheating temperature. There are two main purposes for preheating in the ceramsite sintering process. The first is to pyrolyze most of the organic matter in the sea 
mud into a gas to make the ceramsite lighter. The second is to remove the moisture in the sea mud so as to avoid evaporation of the water during the heating process, which may cause the body to burst and affect the strength of the ceramsite. When the preheating temperature is low, the decomposition rate of the organic matter in the sea mud is gentle, no gas is generated, and the ceramsite expansion rate is not high. At this time, when the gas escapes from the ceramsite, the pores formed on the surface are small, so the ceramsite bulk density and compressive strength are high. As the preheating temperature increases, the gas generated by the decomposition of organic matter increases, the pores inside and on the surface of the ceramsite increase, the expansion ratio increases, and the bulk density and compressive strength decrease. However, when the preheating temperature exceeds a certain value, too much gas generated by the organic matter may excessively impact the surface of the ceramsite, causing the sintered body to crack and being difficult to expand. Which in turn affects the expansion rate and compressive strength of the ceramsite. Therefore, it is important to choose a reasonable preheating temperature and preheating time.

The preheating temperature of $350^{\circ} \mathrm{C}$ and the preheating time of $15 \mathrm{~min}$ were suggested to be the good preheating conditions considering the light weighting, high strength, and water absorption capacity.

\subsection{Effect of Sintering Conditions on Ceramsite Properties.} The sintering time was controlled as $6 \mathrm{~min}, 9 \mathrm{~min}$, and $12 \mathrm{~min}$, respectively. The preheating temperature and heating rate were described in Section 2.4. The bulk density, water absorption, compressive strength, and expansion rate were analyzed under different sintering time periods.

As shown in Figure 4, except for compressive strength, the longer sintering time showed a higher value, and there were no obvious trends for other three indexes with different sintering time periods. As the temperature increased, the bulk density and water absorption index increased firstly and then decreased. In contrast, the expansion rate and compressive strength showed a reversed trend. There was obvious inflection point of temperature for each index $\left(1020^{\circ} \mathrm{C}\right.$ for bulk density, $1040^{\circ} \mathrm{C}$ for water absorption, $1040^{\circ} \mathrm{C}$ for expansion rate, and $1060^{\circ} \mathrm{C}$ for compressive strength).

According to the analysis, this phenomenon is mainly related to the changes in the interior of the raw material at high temperatures. At a certain temperature, the inside of the raw material will melt and soften to form a certain amount of molten mineral. The sea mud contains various organic impurities, decomposed salts, and flammable minerals and can generate a certain amount of gas at a high temperature to expand and deform the ceramsite. The higher the sintering temperature, the longer the sintering time, the smaller the binding of the ceramsite to the gas expansion, the higher the expansion rate, and the smaller the bulk density. When the sintering temperature rises to a certain value, an excessive liquid phase is generated inside the material ball, which causes the liquid phase viscosity to be too low, the pore structure is destroyed, the pores inside the ceramsite become smaller or less, the ceramsite expansion rate decreases, and the bulk density increases. According to the experimental observation, the rebound phenomenon of water absorption may be related to the excessive sintering temperature or excessive sintering time, which causes the surface of the material ball to be burned through, which makes the surface of the ceramsite more open.

Based on the above results, when the sintering temperature was controlled in the range of $1020^{\circ} \mathrm{C}$ to $1060^{\circ} \mathrm{C}$, the ceramic granules have better properties. The optimum conditions were the sintering temperature of $1040^{\circ} \mathrm{C}$ and the sintering time of $9 \mathrm{~min}$. The property indexes of sintered ceramsite measured under this condition were as follows: the bulk density was $410 \mathrm{~kg} / \mathrm{m}^{3}$, the water absorption rate was $10 \%$, the compressive strength was greater than $3 \mathrm{MPa}$, and the expansion rate was between 1.9 and 2.3.

3.4. Transformation of Dissolved Salts during Ceramsite Production. The DSM from Lianyungang has a high salt content. If the product contains high levels of chloride ions, it may cause moisture absorption, blooming, and corrosion $[6,12]$. The average $\mathrm{Cl}^{-}$content in the raw materials was $2.45 \%$. As Figure 5 shows, when the sintering temperature was lower than $600^{\circ} \mathrm{C}$, the $\mathrm{Cl}^{-}$content in the sea mud does not significantly reduced. Above $700^{\circ} \mathrm{C}$, the $\mathrm{Cl}^{-}$content decreased sharply with the sintering temperature, and when it was greater than about $900^{\circ} \mathrm{C}$, the $\mathrm{Cl}^{-}$content was close to zero (the $\mathrm{Cl}^{-}$content was about 0.07 at $1000^{\circ} \mathrm{C}$ ), indicating that a transfer and conversion of the chlorine element occurred in the sintering process.

The low chlorine content in the produced ceramsite was probably because of the production of $\mathrm{HCl}$ gas during the sintering process. The DSM contained $\mathrm{NaCl}$, $\left(\mathrm{Al}_{2} \mathrm{O}_{3} \cdot \mathrm{SiO}_{2} \cdot 2 \mathrm{H}_{2} \mathrm{O}\right), \mathrm{H}_{2} \mathrm{O}$, and carbon, which are four substances that are indispensable for the preparation of hydrochloric acid. Therefore, when the sintering temperature was above $900^{\circ} \mathrm{C}$, complex chemical changes occur to produce $\mathrm{HCl}$ gas, and chlorine has disappeared and rarely exists in a crystalline and glassy ionic state. The main reactions during this process were suggested as follows [15]:

$$
\begin{gathered}
\mathrm{C}+\mathrm{O}_{2}+4 \mathrm{NaCl} \stackrel{\text { high temperature }}{\longrightarrow} 2 \mathrm{Na}_{2} \mathrm{O}+\mathrm{CCl}_{4} \\
\mathrm{CCl}_{4}+2 \mathrm{H}_{2} \mathrm{O} \stackrel{\text { high temperature }}{\longrightarrow} \mathrm{CO}_{2}+4 \mathrm{HCl} \\
\mathrm{Na}_{2} \mathrm{O}+\mathrm{Al}_{2} \mathrm{O}_{3} \cdot 2 \mathrm{SiO}_{2} \stackrel{\text { high temperature }}{\longrightarrow} \mathrm{Na}_{2} \mathrm{O} \cdot \mathrm{Al}_{2} \mathrm{O}_{3} \cdot 2 \mathrm{SiO}_{2}
\end{gathered}
$$

3.5. Biofilm Formation on DSM Derived Ceramsite for COD and $\mathrm{NH}_{4}^{+}-\mathrm{N}$ Removal. Under continuous water circulation, aeration, and natural light conditions, the biofilm on the surface of the carrier was accumulated. Higher extracellular polymeric substances (EPS) and dehydrogenase activity (DHA) production in the biofilm 


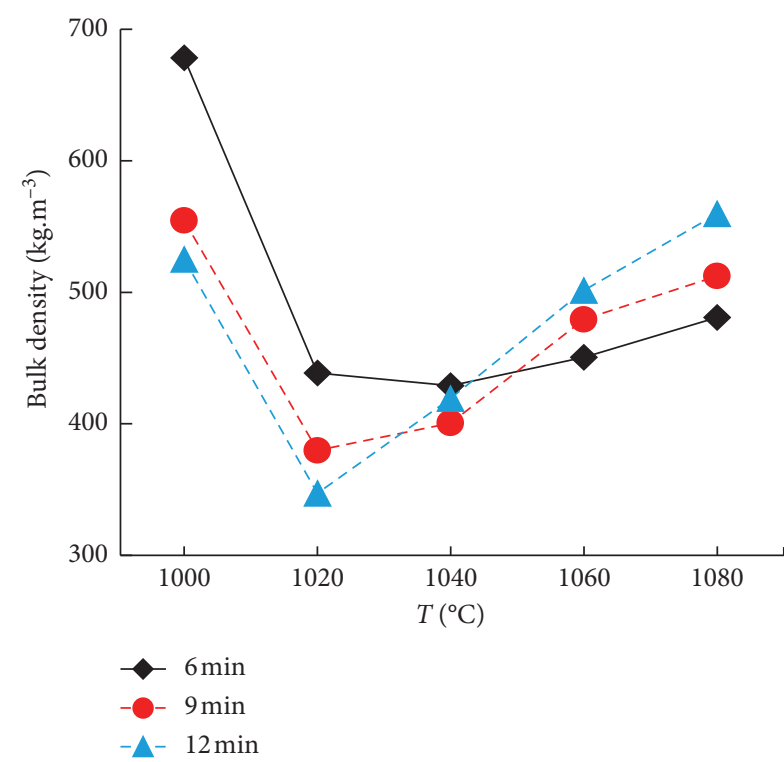

(a)

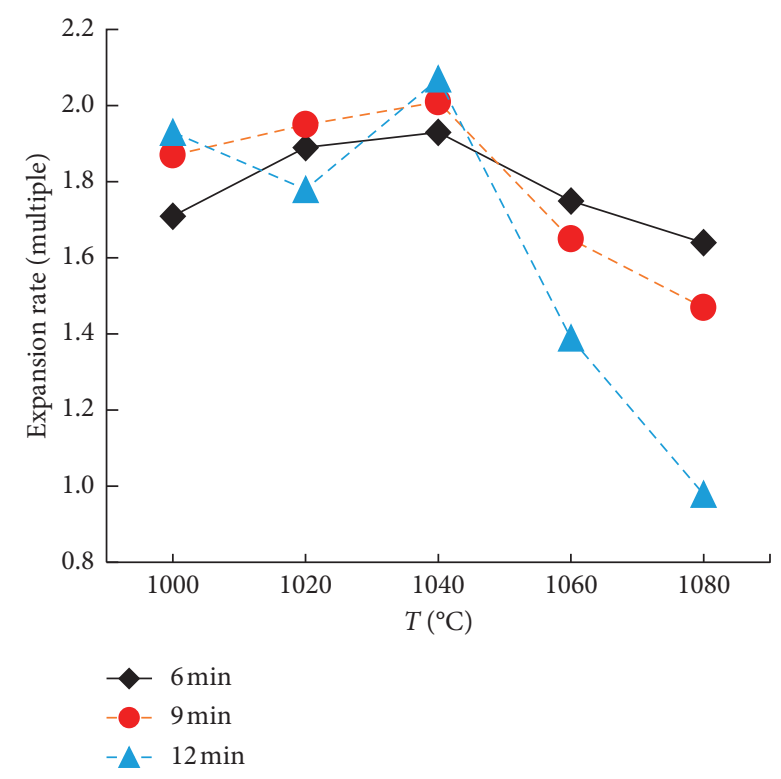

(c)

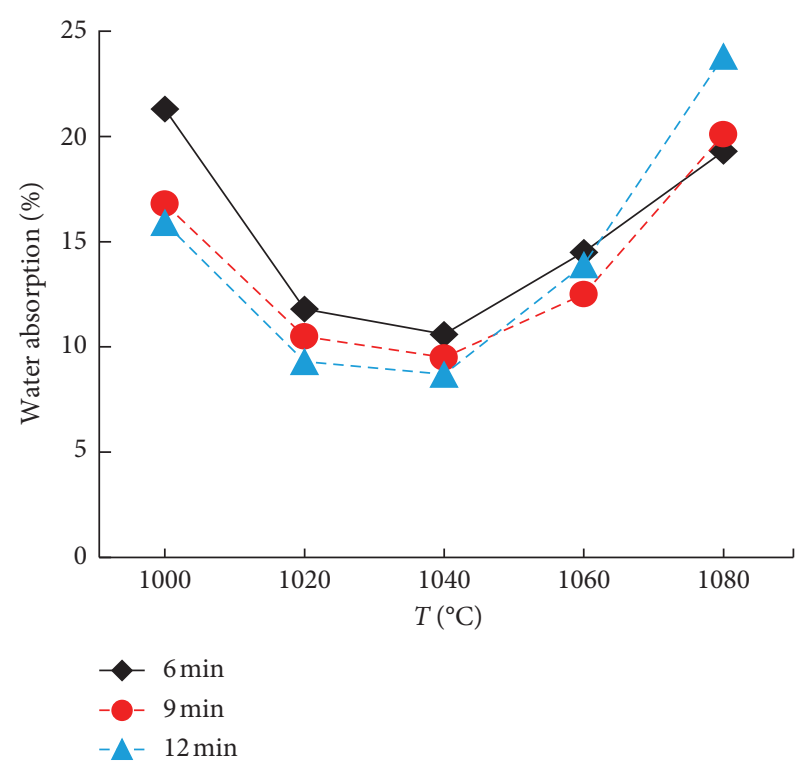

(b)

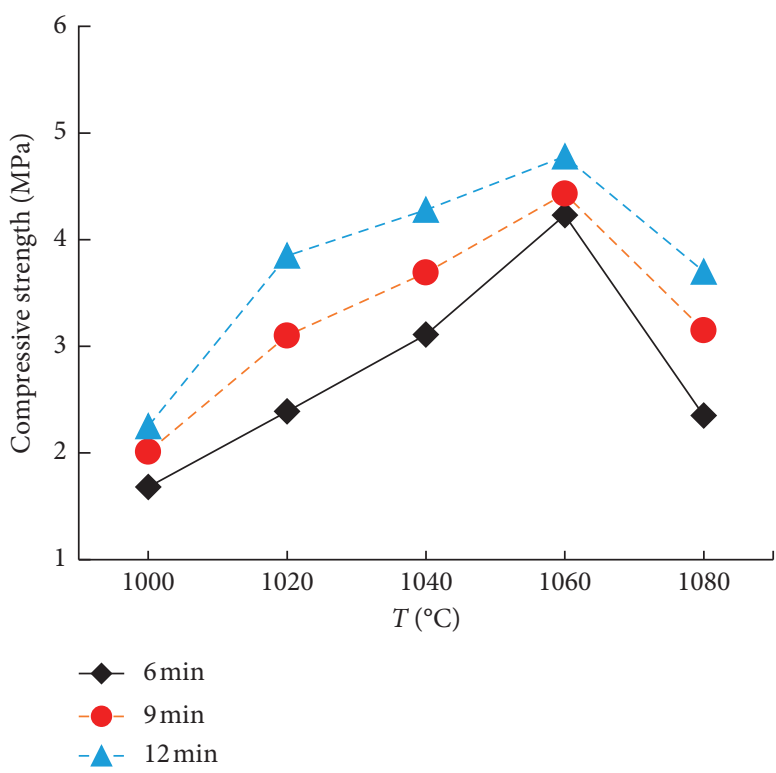

(d)

FIGURE 4: Effect of the sintering system on the performance of marine clay ceramic. (a) Bulk density-temperature curve; (b) water absorption-temperature curve; (c) expansion rate-temperature curve; (d) compressive strength-temperature curve.

formed on the surface of DSM derived ceramsite compared to those produced in biofilm on the surface of commercially ceramsite (clay is the main component). The results are shown in Figure 6. The reason for this is that DSMderived ceramsite has a larger surface area than commercial ceramsite and is more conducive to biofilm deposition.

The removal rates of $\mathrm{COD}$ and $\mathrm{NH}_{4}{ }^{+}-\mathrm{N}$ were also compared between these two filter medias during the test as shown in Figures 7(a) and 7(b). The removal efficiency of COD and $\mathrm{NH}_{4}{ }^{+}-\mathrm{N}$ reached $80.81 \%$ and $65.344 \%$ after 18 days of operation of the column filled with DSM-derived ceramsite, and the DHA value is $1.544 \mu \mathrm{g}\left(\mathrm{h} \cdot \mathrm{cm}^{2}\right)^{-1}$. Therefore, the biofilm formation on the surface of ceramsite can be regarded as mature. In addition, compared with the control group (commercially ceramsite), the removal rate of COD and $\mathrm{NH}_{4}{ }^{+}-\mathrm{N}$ in the DSM-derived ceramsite granules of the experimental group were higher, and this is consistent with the results of more EPS and DHA production for the biofilm on the sea mud-derived ceramsite.

\section{Conclusion}

(1) It is feasible to use DSM from the Lian yungang for ceramsite sintering. The sintered ceramsite has high porosity and surface area.

(2) The optimal conditions for the preheating temperature was controlled at $350^{\circ} \mathrm{C}$, the preheating time 


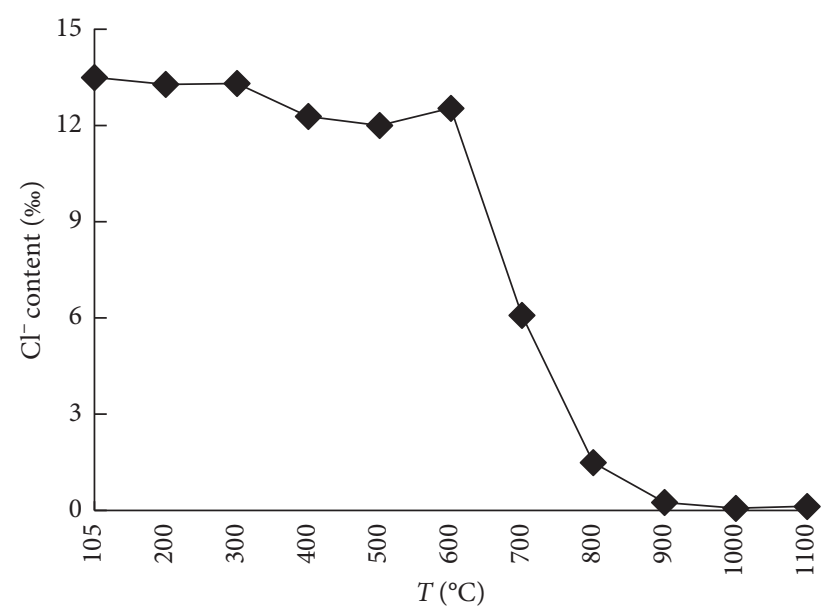

FiguRE 5: Changes of chlorine content with different sintering temperatures.

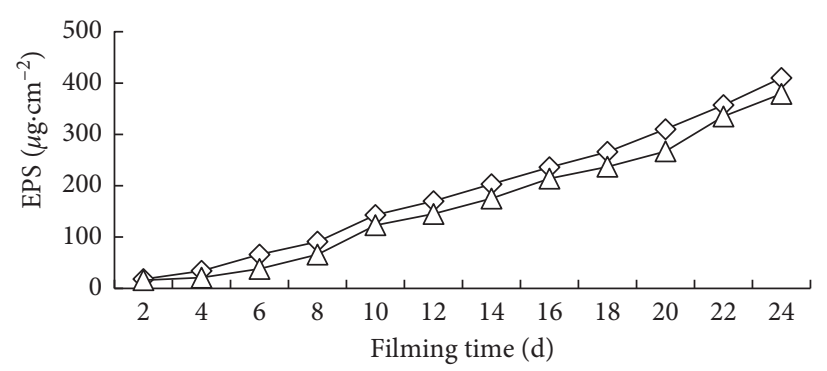

$\checkmark 1 \#$

$\checkmark-2 \#$

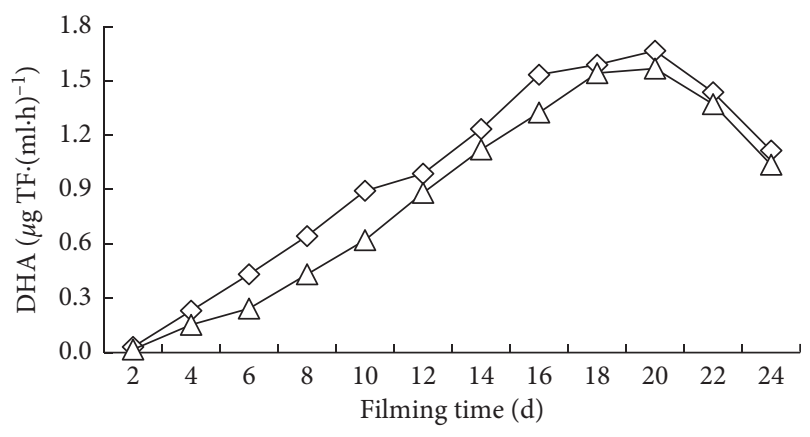

$\checkmark-1 \#$

$-\triangle 2 \#$

(a)

(b)

FIGURE 6: (a) EPS production in the biofilm; (b) DHA production in the biofilm. 1\#: the biocarrier was the DSM-derived ceramsite; 2\#: the biocarrier was the commercial ceramsite

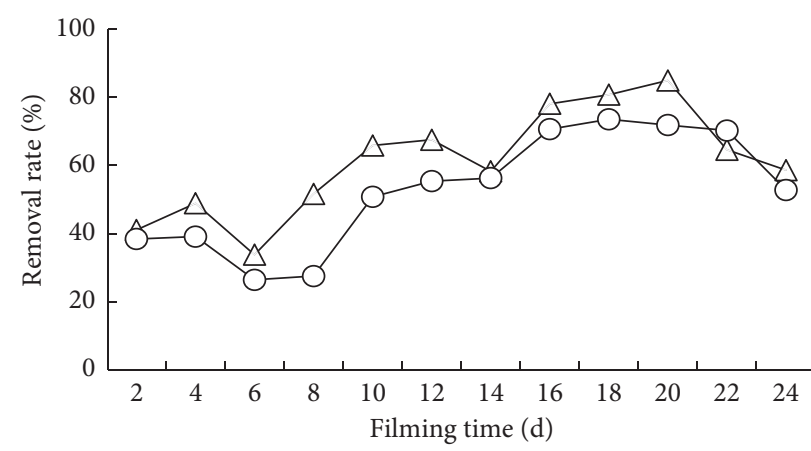

$\triangle 1 \#$

$-0-2 \#$

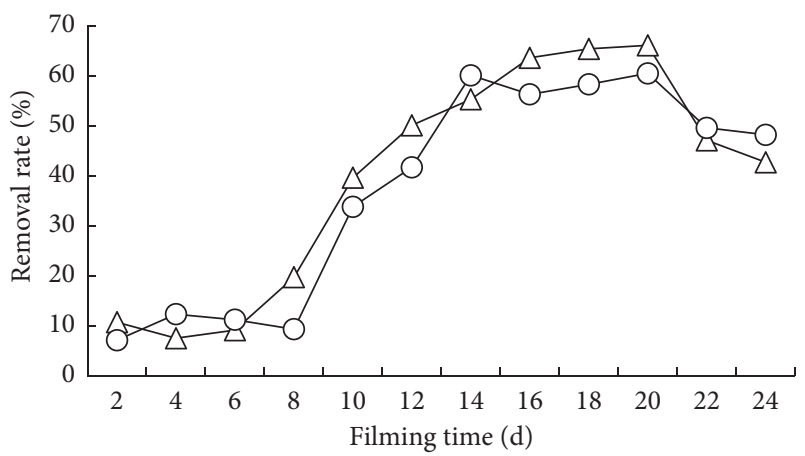

$\triangle-1 \#$

$-0-2 \#$

(a)

(b)

Figure 7: (a) Change of $\mathrm{COD}_{\mathrm{Mn}}$ removal rate during filming. (b) Change of $\mathrm{NH}_{4}{ }^{+}-\mathrm{N}$ removal rate during film hanging. 1\#: the DSM-derived ceramsite condition; $2 \#$ : the commercial ceramsite condition.

was $15 \mathrm{~min}$, the sintering temperature was $1040^{\circ} \mathrm{C}$, and the sintering time was $9 \mathrm{~min}$. Under this condition, the bulk density of produced ceramsite was
$410 \mathrm{~kg} / \mathrm{m}^{3}$, the water absorption rate was $10 \%$, the compressive strength was above $3 \mathrm{MPa}$, and the expansion rate was around 2, which was classified 
as ultralightweight ceramsite according to $\mathrm{GB} / \mathrm{T}$ 17431.1-2010.

(3) The content of the chloride ion in the ceramsite granules prepared by DSM is close to zero, and the content of soluble chloride ions is extremely low.

(4) The sea mud-derived ceramsite showed better biofilm formation capacity with high COD and $\mathrm{NH}_{4}{ }^{+}-\mathrm{N}$ removal capacity compared with the commercial ceramsite (clay is the main component).

\section{Data Availability}

We declare that the materials described in the manuscript, including all relevant raw data, will be freely available to any scientist wishing to use them for noncommercial purposes, without breaching participant confidentiality.

\section{Conflicts of Interest}

The authors declare that there are no conflicts of interest regarding the publication of this paper.

\section{Acknowledgments}

This work was supported by China's National Water Pollution Control and Governance of Science and Technology Major Special (2018ZX07208-004).

\section{References}

[1] M. Li, Z. Zhang, K. Xu et al., "Pilot experimental research on sintering perforated brick from dredged sea sediments," Journal of Computational and Theoretical Nanoscience, vol. 13, no. 4, pp. 2616-2622, 2016.

[2] J. Xie, X. C. Lin, P. Shi et al., "Study on using sea dredged mud to produce light weight Aggregate," Journal of Zhanjiang Ocean University, vol. 24, no. 6, pp. 32-36, 2004.

[3] Z. G. Li, "Study on calcining clay brick by using silt and sea mud," Brick and Tile World, vol. 5, pp. 43-45, 2006.

[4] W. Zhu, Z. C. Feng, C. L. Zhang, and J. Xie, "Study on the field test of reclamation for dredging mud," China Harbour Engineering, vol. 4, no. 5, pp. 23-25, 2005.

[5] X. Xie, L. Zhang, S. Liu, T. Zhang, and H. Yang, "Aerated sea mud is beneficial for post-nursery culture of early juvenile sea cucumber Apostichopus japonicus, (Selenka)," Aquaculture International, vol. 24, no. 1, pp. 211-224, 2016.

[6] P. Y. Chi, L. D. Zhang, Q. Qian et al., "Research on light ceramsite made by silt sea mud," Insulation Materials and Building Energy Saving, vol. 3, pp. 28-30, 2002.

[7] C. Jiang, L. Jia, B. Zhang, Y. He, and G. Kirumba, "Comparison of quartz sand, anthracite, shale and biological ceramsite for adsorptive removal of phosphorus from aqueous solution," Journal of Environmental Sciences, vol. 26, no. 2, pp. 466-477, 2014.

[8] T. P. Li, T. T. Sun, and D. X. Li, "Preparation, sintering behavior, and expansion performance of ceramsite filter media from dewatered sewage sludge, coal fly ash, and river sediment," Journal of Material Cycles and Waste Management, vol. 20, no. 1, pp. 71-79, 2018.

[9] G. R. Xu, J. L. Zou, and G. B. Li, "Ceramsite obtained from water and wastewater sludge and its characteristics affected by
$\left(\mathrm{Fe}_{2} \mathrm{O}_{3}+\mathrm{CaO}+\mathrm{MgO}\right) /\left(\mathrm{SiO}_{2}+\mathrm{Al}_{2} \mathrm{O}_{3}\right)$," Water Research, vol. 43, no. 11, pp. 2885-2893, 2009.

[10] D. T. Yue, Q. Y. Yue, B. Y. Gao et al., "Preparation and bloating mechanism of porous ultra-lightweight ceramsite by DehydratedSewage sludge and yellow river sediments," Journal of Wuhan University of Technology-Mater, vol. 29, no. 6, pp. 1129-1135, 2014.

[11] S. Wang, S. Li, Y. Zhao, and Z. Wei, "Removal of cadmium from aqueous solutions using ceramsite mainly composed of $\mathrm{Pb}-\mathrm{Zn}$ tailings," Journal of Residuals Science and Technology, vol. 13, no. 2, pp. S1-S5, 2016.

[12] Y. Y. Liu and T. Xia, "Study on ceramsite production with sludge and sea mud in municipal sewage plant," Industrial Safety and Environmental Protection, vol. 3, pp. 18-21, 2016.

[13] M. D. Li, T. Xia, Y. Y. Liu et al., "Experimental research on sintering ceramsite of dredged saline sediment from seaport," Journal of Chongqing Jiaotong University (natural science), vol. 35, no. 6, pp. 81-85, 2016.

[14] M. Gao, A. G. Tian, M. D. Li et al., "Experimental research on key technology of dehydration desalination for sea siltbrick making," New Building Materials, vol. 40, no. 2, pp. 35-37, 2013.

[15] M. Li and X. Cong, "Chemical changes and the mechanisms in the sintering process of sea silt," Bulgarian Chemical Communications, vol. 49, no. 1, pp. 250-255, 2017.

[16] X. R. Wang, Y. Y. Jin, X. Du et al., "Feasibility research on sintering municipal sewage for manufacturing haydite," China Water and Wastewater, vol. 23, no. 7, pp. 11-15, 2007.

[17] Y. H. Yang, Z. A. Wei, Y. L. Chen, Y. Li, and X. Li, "Utilizing phosphate mine tailings to produce ceramisite," Construction and Building Materials, vol. 155, no. 30, pp. 1081-1090, 2017.

[18] Z. H. Yang, W. J. Song, J. H. Yang, L. Deng, Z. Cao, and M. L. Shi, "High-strength ceramsite made with sludge and low-quality fly ash," Journal of Materials in Civil Engineering, vol. 25, no. 7, pp. 851-856, 2013.

[19] J. Qin, C. M. Yang, C. Cui, J. Huang, A. Hussain, and H. Ma, "Ca $2+$ and $\mathrm{OH}-$ release of ceramsites containing anorthite and gehlenite prepared from waste lime mud," Journal of Environmental Sciences, vol. 47, pp. 91-99, 2016. 


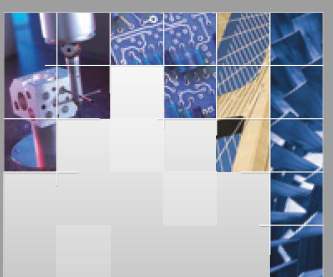

\section{Enfincering}
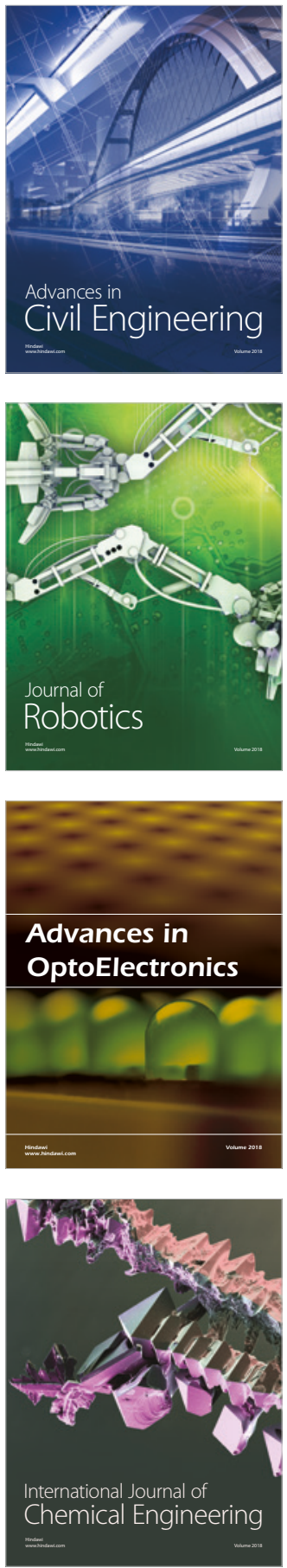

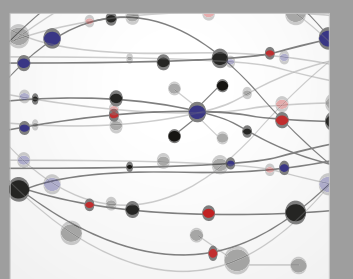

\section{Rotating \\ Machinery}

The Scientific World Journal

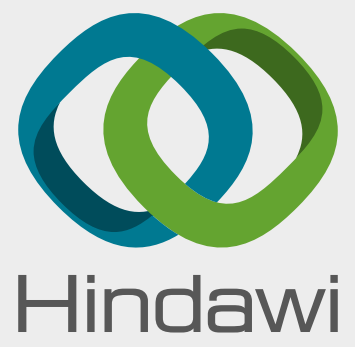

Submit your manuscripts at

www.hindawi.com
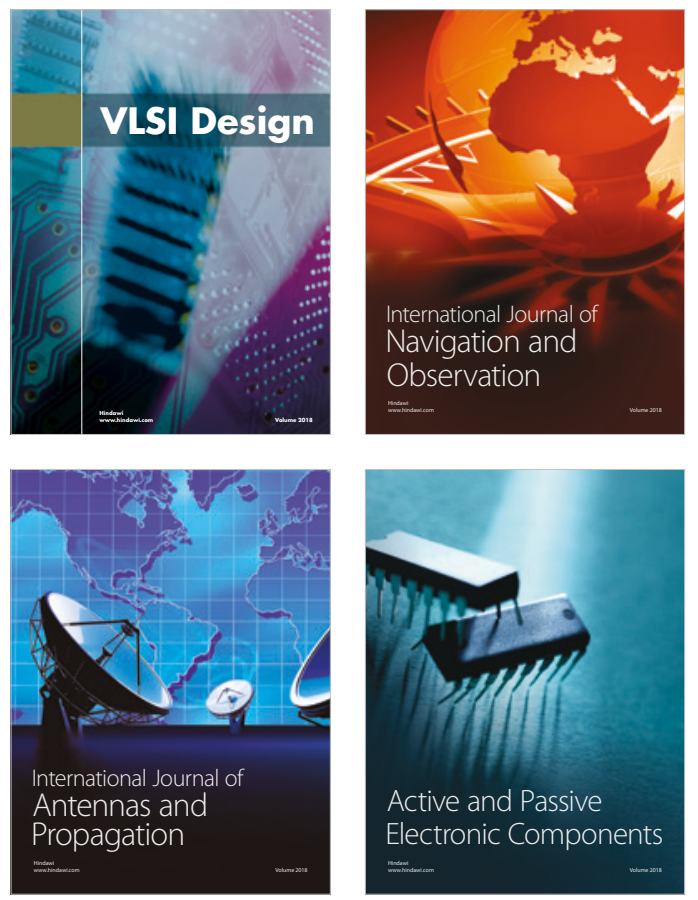
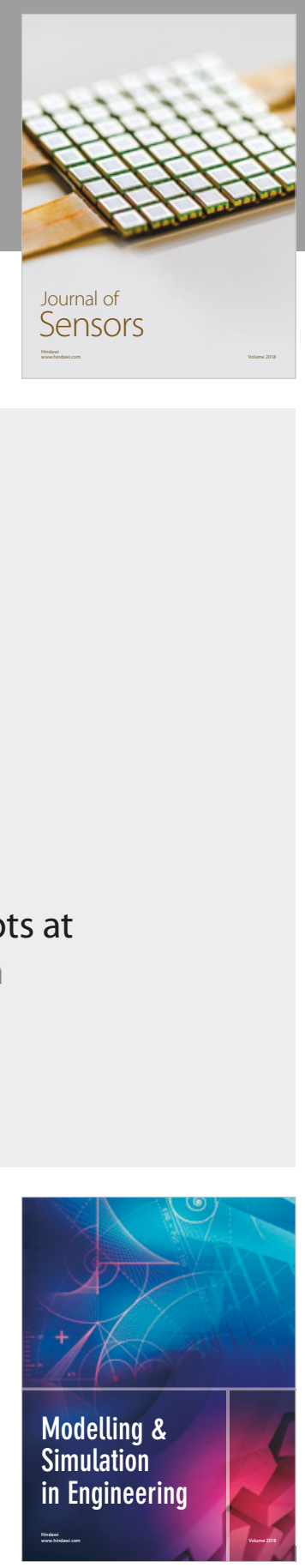

\section{Advances \\ Multimedia}
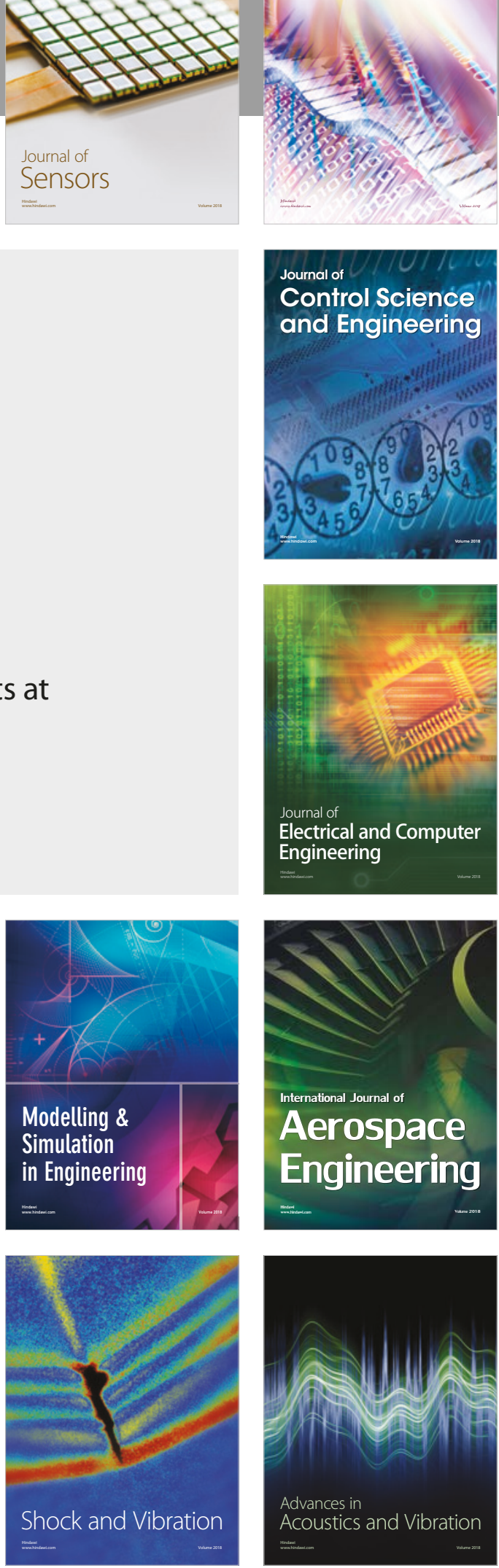